\section{Agricultural Extension Models in South America: A Description of Systems in Use in Argentina, Brazil, Paraguay, and Uruguay}

\author{
Jorge Arboleya ${ }^{1}$ and \\ Ernesto Restaino ${ }^{2}$
}

Additional INDEX WORDS. technology transfer, research systems, extension, farmer linkages, MERCOSUR

SUMmARY. Information is presented about the linkages and relationships between the research and the transfer of technology-extension systems established within the countries that compose the Common Market of the South [Mercado Común del Sur (MERCOSUR)]. A brief description about the history of agricultural extension in each country is included along with descriptions of the major changes that have occurred within the last 10 years. This analysis allows a general comparison among the different extension approaches, and in particular regarding the institutional development for the system in the four countries of MERCOSUR.

$\mathrm{M}$ ajor changes occurring in the last decade were distinguished by structural and functional institutional changes, with emphasis in transferring responsibilities from governmental to nongovernmental organizations. Clientele and stakeholder

We thank Gerardo Bergamin from Universidad Nacional de Cordoba, Carlos Alemany, National Institute of Agriculture Technology Estación Agropecuaria Alto Valle, Argentina; Francisco Roberto Caporal Technical Assistantce and Rural Extension Enterprise, Porto Alegre; Dilson Bisognin, Universidad Federal de Santa María, Brazil; and Douglas Sanders, North Carolina State University, for contributing information or suggestions and for advice provided in the preparation of this paper.

${ }^{1}$ Ing. Agr. MS., Dept. of Horticulture, National Agriculture Research Institute, URUGUAY, jarboley@inia.org.uy.

${ }^{2}$ Ing. Agr. MS., Technology Transfer, National Agriculture Research Institute, URUGUAY, restaino@inia.org.uy. participation in guiding research and extension activities was substantial in some of the countries (demand-driven model). Vertical integration of farmers, suppliers, processors, research, and extension in defining technological problems and finding solutions was successfully carried out in some commodities.

\section{Introduction to the MERCOSUR}

Argentina, Brazil, Paraguay, and Uruguay (Fig. 1) signed the Tratado de Asunción establishing the MERCOSUR in March 1991. Subsequently, in Ouro Preto, Brazil, the Protocolo de Ouro Preto established the institutional structure of MERCOSUR in 1994, and later, Chile and Bolivia became associate members (MERCOSUR, 2002). The growth of national markets through this integration has been a fundamental condition leading to the acceleration of economic development in each of the member countries. Such changes, however can only be achieved while making the most efficient use of available resources, preserving the environment, improving physical links, coordinating macroeconomic policies and complementing the various productive sectors of the economy.

By the end of 1999, the MERCOSUR and the associated member countries (Chile and Bolivia) had reached a total domestic market represented by 223 million people ( $4 \%$ of world popula-

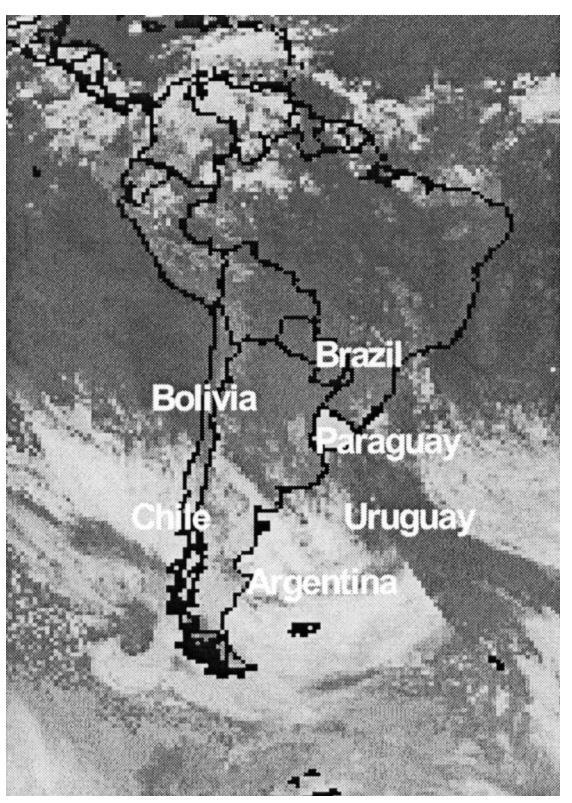

Fig. 1. Map of South America with identification and location of the Common Market of the South [Mercado Común del Sur (MERCOSUR)] countries. tion) and a total land of $\approx 10 \%$ of the total world area. In particular, MERCOSUR account for $70 \%$ of the total of South American land area, and 58\% of South America's gross domestic product [Sawaya et al., 1998; Instituto Interamericano de Cooperación para la Agricultura (IICA; Interamerican Institute of Agriculture Cooperation), 2001]. The agrofood sector of MERCOSUR is a strategic sector, being responsible for $\approx 43 \%$ ( $5 \%$ from agricultural commodities and 38\% from industrialized food and drinks) of the total exports (IICA, 2001). Consequently, the sustainable development, modernization, and efficiency of the agricultural sector in each of the countries are essential. A key element, in addition to policies and markets, is the structure, organization, and outreach of the research-technology transfer-extension system.

\section{Extension background of selected countries of the MERCOSUR}

\section{Uruguay}

In 1914, the Instituto Fitotécnico y Semillero Nacional (National Plant Breeding and Nursery Institute) was established which was a pioneer agricultural research organization both in Uruguay and in South America. However, extension programs based on technical assistance outreach was not introduced until 1950 (Allegri et al., 1987; E. Indarte, unpublished). In 1961, the Instituto Fitotécnico y Semillero Nacional was reorganized and renamed as the Centro de Investigaciones Agrícolas Alberto Boerger (CIAAB; Alberto Boerger Agricultural Research Center), broadening its goals [Allegri et al., 1987; Instituto Nacional de Investigación Agropecuarias (INIA; National Agricultural Research Institute), 2000a].

As described by Restaino (2001), today's Uruguay has a broad number of institutions associated with the research, technology transfer and extension system (Fig. 2). This national system may be divided an analyzed into two subsystems: 1) the technology generation subsystem, and 2) the technology transfer and extension component ( $\mathrm{Al}$ legri, 1999).

THE TECHNOLOGY GENERATION SUBSYSTEM. Four parties represent this technology generation subsystem: INIA, which represents $\approx 90 \%$ of the national investment in agricultural research (Allegri, 1999); 
the University of the Republic, with colleges of agriculture and veterinary medicine; the Ministerio de Ganadería Agricultura y Pesca (MGAP; Ministry of Livestock, Agriculture, and Fisheries) through the Laboratorieos Veterinarios Miguel C. Rubino (Miguel C. Rubino Veterinarian Laboratory Research Center); and the Secretariado Uruguayo de la Lana (SUL; Uruguayan Wool Secretariat).

THE TECHNOLOGY TRANSFER AND EXTENSION SUBSYSTEM. This subsystem is multi-institutional and may be grouped into four clusters.

1) Public organization or programs managed by the MGAP. This group includes few activities that are directed to small farmers, such as horticulture and fruit production, which occur under the auspices of the Junta Nacional de la Granja(JUNAGRA; National Fruit and Horticulture Council,) (JUNAGRA, 2000; MGAP, 2000). This practice is consistent with the governmentstrategy of transferring financial responsibility of extension activities to the private or semi-private sectors.

2) Public organizations associated with the MGAP. In this case, the public and private sectors share the management and control of these organizations. Examples of this cluster are INIA, the Instituto Plan Agropecuario (IPA; Plan Farming Institute), the Instituto Nacional de Semillas (INASE; National Seed Institute), and SUL. INIA and SUL also have research responsibilities; IPA's responsibility is extension.

INIA was created in 1989 by congressional law and has two major objectives. The first is to promote and implement agricultural research activities in order to contribute to sustainable development within the agricultural sector. The second is to achieve effective transfer of the generated technology through effective interaction with the technical assistance and extension organizations that belongs to either the public or the private systems (INIA, $2000 \mathrm{~b}$ ). One of the most important statutory changes regarding INIA was the inclusion of regional advisory councils (RACs) in its mandate. These advisory councils are comprised of farmers, professionals, and representatives from the main professional association and their main roles are to provide advice on technological problems and to contribute to priority setting (Restaino, 1998). There are also working groups (WGs) for each commodity and/or production system. Moreover, farmers contribute to the INIA budget through a tax of $0.4 \%$ of gross farm sales. The total budget for INIA comes from this tax and from an equal amount of funding provided by the government.

RAC members and INIA's research staff found the application of RAC highly successful, over the past ten years, in identifying technological needs and educational extension activities, prioritizing research and extension programs, and as an important tool to establish linkages with stakeholders (Restaino, 2003).

IPA is one of the most important institutions working in extension. It works cooperatively with INIA and also uses other sources of information and technology in developing its extension programs (IPA, 2000).

INASE, another public nongovernmental organization, is a further example of moving responsibility from the government to a nongovernmental organization. Its principal goals are to promote the production and the use of high-quality seed of known origin (INASE, 2002).

SUL, focused mainly on the generation and transfer of technologies for the sheep breeders and wool industry since 1966, providing training, guidance and information, insuring quality control of wool and meat production processes, as well as providing overseas consultancy services (SUL, 2000).

3) Public organizations that are not associated with the MGAP. This segment of public organizations includes the University of the Republic, the Bank of the Republic (BROU) and individual state governments.

The University of the Republic (of Uruguay), through its colleges of agriculture and veterinary medicine, develops independent research and extension programs.

Most county government offices have established agricultural development agencies in order to promote the development of specific regions or products. In general those offices employ extension agents who help farmers within the county boundaries.

4) Nonprofit private organizations. The technical assistance that is organized, provided, and financed by the private sector has grown considerably in recent years and has become a very important mechanism for technology transfer. It has proven to be dynamic and highly successful. The most important participants in this segment are:

The cooperative movement has a long history in Uruguay (Ferrin, 1991). Today, $\approx 60$ agricultural cooperatives

Fig. 2. The linkages and organization of the multiple national system of generation-technology transfer-extension in Uruguay. BROU = Bank of the Uruguayan Republic; CREA = Regional Councils of Agricultural Experimentation; INASE = National Seed Institute; INIA = National Agriculture Research Institute; IPA = Plan Agropecuario Institute; JUNAGRA $=$ National Fruit and Horticulture Council; MGAP-DILAVE = Miguel C. Rubino Veterinarian Laboratory Research Center; MGAP = Ministry of Livestock, Agriculture, and Fisheries of Uruguay.

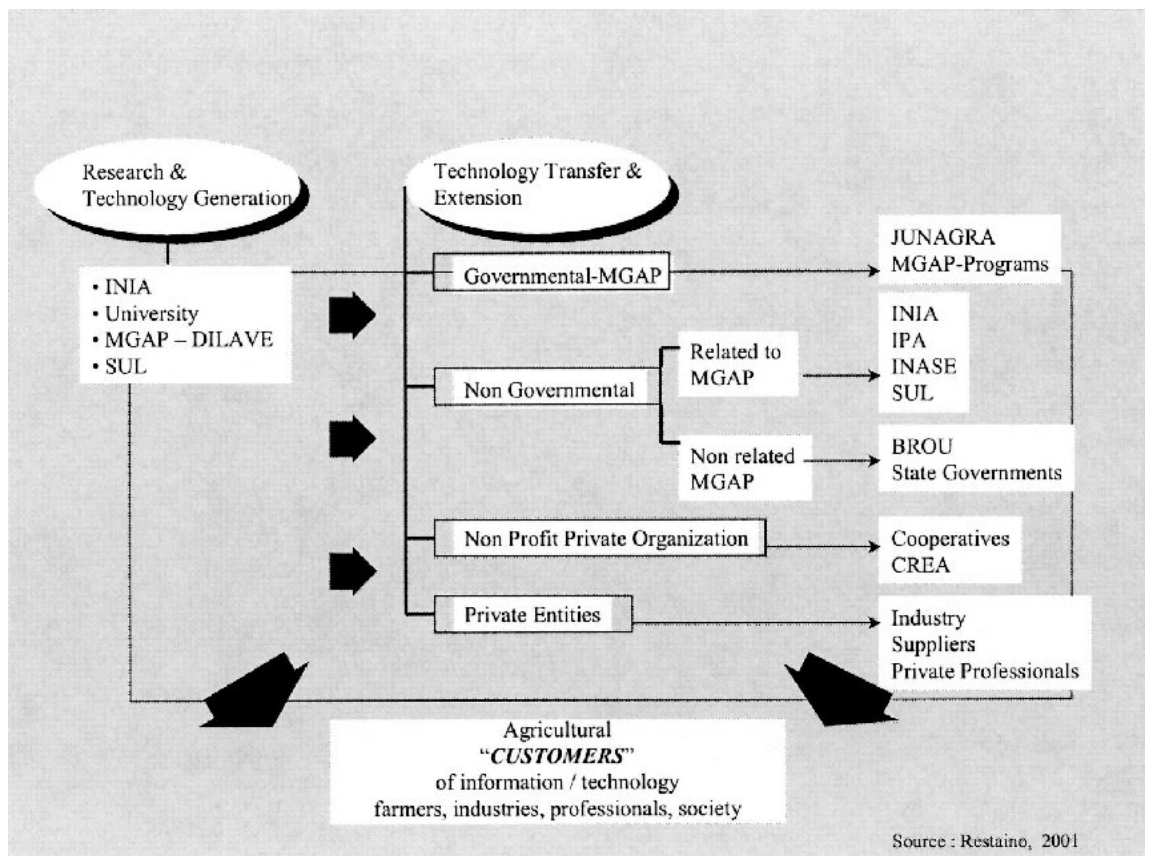

Hortlechnology • January-March 2004 14(1) 
serve a large number of farmers. They specifically serve small and mediumsized enterprises. The most important roles of these cooperatives are related to supplying basic agriculture inputs, providing sales and managerial operations, and farm advice directly to the associated farmers.

5) Consejos Regionales de Experimentación Agropecuaria (CREA; Regional Councils of Agricultural Experimentation Groups). These councils are self-managed groups that work and meet periodically to share farming experiences, to analyze problems and to search for solutions using participatory approaches.

6) Private entities. The activities of the private sector are important in the technology-transfer-extension process. This group includes the food-processing sector, input suppliers, and private consultants. The development of this segment has recently become very important in Uruguay. Private consultants such as agronomists, veterinarians, and technical experts are important in facilitating extension and technology transfer activities.

\section{Argentina}

The Instituto Nacional de Tecnología Agropecuaria (INTA; National Institute of Agricultural Technology), was created in 1956 to encourage and advance the development of research and extension, and to improve the profitability of agriculture businesses and the quality of rural life (Alemany, 2002). The origin of extension in INTA was based on a requirement of the Ministry of Agriculture to disseminate information throughout the countryside through the Agencias de Extensión Rural (Extension Service Agencies). There were more than 200 such agencies in the country. Each agency had one agronomist or veterinary doctor (as the director of the agency), one counselor who specialized in economics, and one technician who worked with young people in the agriculture community. The result of their work was excellent and INTA became recognized in the rural areas, not only from an agricultural standpoint, but also for the social component promoted. The development and education of local leaders was one approach used to facilitate the transfer of technology and to influence change in grower's attitudes.

During the 1970s, the objective of extension within INTA changed as a result of a shift in the macro politics of the country (Alemany, 2002). The shift was away from a focus on social and human factors toward a new emphasis promoting the adoption of modern technologies and crop varieties with a particular focus on medium-sized growers. Small growers and small farmsteads were not included in the new approach.

In the mid 1980s, the institution was again reorganized into what was called INTA II. This reform gave an important role to regional areas through the formation of Consejos de Centro Regionales (Centers of Regional Councils). In this way all those involved could interact to establish their own objectives, to propose the specific strategies and to support each other. The INTA's Regional Councils, as compared to the INIA Uruguay, also have responsibilities regarding budget allocation at the regional level as well as being as policy makers for the region (Restaino, 2003).

\section{Brazil}

The extension system in Brazil was begun in the 1950s and was based on the model used in the U.S. (i.e., teaching, research, and extension) and was focused largely in the state of Sao Paulo (Caporal, 2001; Oliveira, 1999). Later, rural extension was begun as the Asociación de Crédito y Asistencia Técnica (Technical Assistance and Loan Association). Extension was also implemented in the northern region of the country using the three components of the U.S. model where it was supported by Banco do Nordeste (Northeastern Bank), Banco do Brasil (Brazilian Bank), Universidade Rural (Rural University), and other organizations. The association typically employed extension agents, agriculture specialists, and social specialists.

From 1950-60 the goal of the rural extension in Brazil was to improve agricultural production and rural family income, and focused in small rural families. From 1960, the rural extension changed to support medium to big-grower enterprises to export agriculture products, and in the 1970s changed back the attention small rural families.

The Empresa Brasilera de Pesquisa Agropecuaria (EMBRAPA; Agricultural Research Enterprise) was founded in 1973 to promote, to encourage, to coordinate, and to execute agricultural research activities in Brazil.
Similarly in 1976, the Empresa Brasilera de Asistencia Tecnica y Extensao Rural (EMBRATER; Technical Assistance and Rural Extension Enterprise) was created to develop extension programs and $\mathrm{co}^{-}$ ordinate extension services within the country, in agreement with EMBRAPA (Caporal 2001; Marques and Goes de Oliveira, 1987).

\section{Paraguay}

In 1923, the División de Agricultura y Defensa Agropecuaria was formed with the objective of promoting the production of cotton (Gossypium spp.), tobacco (Nicotiana glauca) and other commodities important for the economy in Paraguay (Beintema et al., 2000). In 1943, agronomists from Paraguay and the U.S. created, the Instituto Agronómico Nacional (IAN; National Agriculture Institute) in Caacupé, 50 $\mathrm{km}$ (31.1 miles) from Asunción and the Barreiro Research Station in Caapucú, $150 \mathrm{~km}$ (93.2 miles) south of Asunción. Another research station, in Capitán $\mathrm{Mi}$ randa, was established in 1953, which was converted to the Centro Regional de Investigación Agrícola (CRIA; Regional Center of Agriculture Research) in 1970. Its research focused on fruit, soybean (Glycinemax), corn (Zea mays), cotton, and wheat (Triticum aestivum). Separately in 1966, the Ministry of Agriculture was reorganized and the $\mathrm{Di}$ rección de Investigación Agropecuaria y Extension Rural (National Direction of Research and Rural Extension) was formed.

In addition, in 1972, the Centro Experimental Agropecuario de Paraguay (Research Agriculture Center of Paraguay) was created (Beintema et al., 2000). In 1988, it became the Centro Tecnológico Agropecuario de Paraguay (CETAPAR; Agricultural Technology Center of Paraguay)]. Its objectives are to develop research and extension for tomato (Lycopersicum esculetum), soybean, wheat, cattle, and grass production, which are the most important crops for Japanese growers, an important immigrant community in Paraguay. CETAPAR has been under the auspices of Japan International Cooperation Agency (JICA) since 1985.

Major research and extension development occurred in the last decade.

One of the most dynamics changes occurring in the MERCOSUR countries during the last decade has been the institutional restructure and reorganization 
of the research and extension agencies. For instance, in 1990 in Brazil, EMBRAPA was eliminated and each state becomes responsible for their extension programs following state policies [Caporal, 2001; Empresa de Asistencia Tecnica y Extensao (EMATER; Rural Technical Assistance and Rural Extension Enterprise), 2002). For example in the state of Santa Catarina, the Empresa de Pesquisa Agropecuaria y Extensao Rural de Santa Catarina (EPAGRI; Research and Extension Enterprise of Santa Catarina) was formed as the institution responsible for research and extension in that region (EPAGRI, 2002).

Argentina created an extension program named Cambio Rural (Rural Change) in 1993 (INTA, 2003a), to support the development of mediumsized agricultural enterprises. This program is under the combined supervision of INTA, the National Agriculture and Food Secretary, state governments and agricultural enterprises. It objectives is to encourage and to strengthen the work of grower groups that are developing various forms of organizations, and to promote the development of individual growers. Each grower group has a designated extension agent who provides training and who is directed by project directors who are in permanent contact with INTA researchers and extension agents. Through the extension agents, growers are provided with information about crop management, agriculture business administration, organization, marketing, etc. Argentina also created an additional extension program, food security program for poor people, entitled PRO-HUERTA, having the objective of increasing the production of vegetables for self-consumption throughout the poorest segments of the rural communities (INTA, 2003b). This program is also governed by INTA, but was founded by the Environmental and Social Development Ministry. A program named Minifundio (INTA, 2003c) was also developed to improve income and life quality of smallholding growers.

In Paraguay, the Dirección de Investigación Agropecuaria (DIA; Institute of Agriculture Research) was created as one of the three branches of the Ministry of Agriculture in cooperation with the Department of Transfer of Technology Paraguay (Beintema et al., 2000). As described previously, CETAPAR is responsible for research, extension, and transfer of technology mainly for assisting the immigrants Japanese growers established in this country. For example, CETAPAR introduced higher-yielding soybean varieties cultivated by $45 \%$ of the Japanese growers. The cooperation between CETAPAR and DIA is active and effective.

In Uruguay, INIA, JUNAGRA, IPA, and INASE were all developed during the last 10 years. The latest reorganization of the research system (INIA) incorporated a modern concept where research programs are directed by farmers and by the needs of the various agricultural industries. This change was one of the most important of the last decade (i.e., the inclusion of a demand-driven model). The shift of responsibilities from government to the nongovernmental, nonprofit organization of technology transfer-extension (IPA) has led to a dynamic and modern organization that meets the needs of today's farmers

Some organizations such as INIA, IPA, and INASE, function with a board of directors, which includes representatives from the principal farmers' associations, a very important and modern concept. As principal customers, farmers are directly involved in the decisions and responsibilities of those organizations which ensures very strong demand-driven model practices and participatory involvement (Allegri, 1999). However, recent evaluations indicate the need for improving communication and accountability to stakeholders and clientele (Restaino, 2003).

Diversity is one of the main characteristics of the multiple technology transfer-extension system in Uruguay. Farmers have the advantage of access to many sources of information and several institutions that can respond to the agricultural sector's problems. However, this complex multi-institutional system leads to duplication and competition among institutions working who are working for the same customers even though the institutions have different perspectives. The establishment of future partnerships (strategic alliances, networking, social capital, etc.) to promote more efficient development and to optimize resources should become priorities for resolving these issues $(\mathrm{Al}-$ legri, 1999; Restaino 2003).

Over the last decade, Argentina, Brazil, and Uruguay have produced a greater number of extension bulletins and videos for disseminating crop technical management knowledge than ever before. Furthermore, more individuals (extension agents, consultants, and growers) have had access to email and to the Internet, which has improved and facilitated communication.

Weather forecasting became an important tool during this period allowing consultants, extension agents, and growers to improve field management decisions. This capability has been most important in Brazil [Instituto Nacional de Pesquisas Espaciales (INPE); National Institute for Space Research, 2002], less important in Argentina (INTA, 2003d), and least important in Uruguay (INIA, 2000c).

Several changes have taken place during the past 10 years in relation to educational activities that involved extension professionals, consultants, and growers. These activities included organizing field days, demonstrations in situ, workshops, videos, radio interviews, stakeholders' educational meetings, and grower roundtables. In Uruguay, the grower roundtables are organized as self-directed groups working to identify solutions to production and processing problems. The groups are composed of specialists from INIA, the Laboratorio Tecnológico del Uruguay (LATU; Technological Laboratory of Uruguay), the College of Agronomy from the University of the Republic of Uruguay, and representatives from the food-processing sector. Currently in Uruguay there are barley (Hordeum vulgare), wheat, rice (Oriza sativa), garlic (Allium satioum) and onion (Allium cepa), tomato, citrus (Citrus spp.), and forestry roundtables working in this manner.

INTA La Consulta in Mendoza, Argentina, has been organizing garlic workshops every 2 years (Burba, 1992 , 1993, 1995, 1997, 1999, 2001). Updated research and extension results are presented at these meetings. Researchers, extension agents, growers, and industry representatives discuss the problems of production, technology transfer, and commercialization of garlic.

The MERCOSUR onion council was established in 1996 in Ituporanga, Santa Catarina, Brazil. The council met in Bahia Blanca, Argentina in 1997; in Salto, Uruguay in 1999; and in Brazil in 2001 (Arboleya et al., 1999). Onion research results and extension activities are updated and coordinated at these meetings and growers have the opportunity to interact and to interchange 


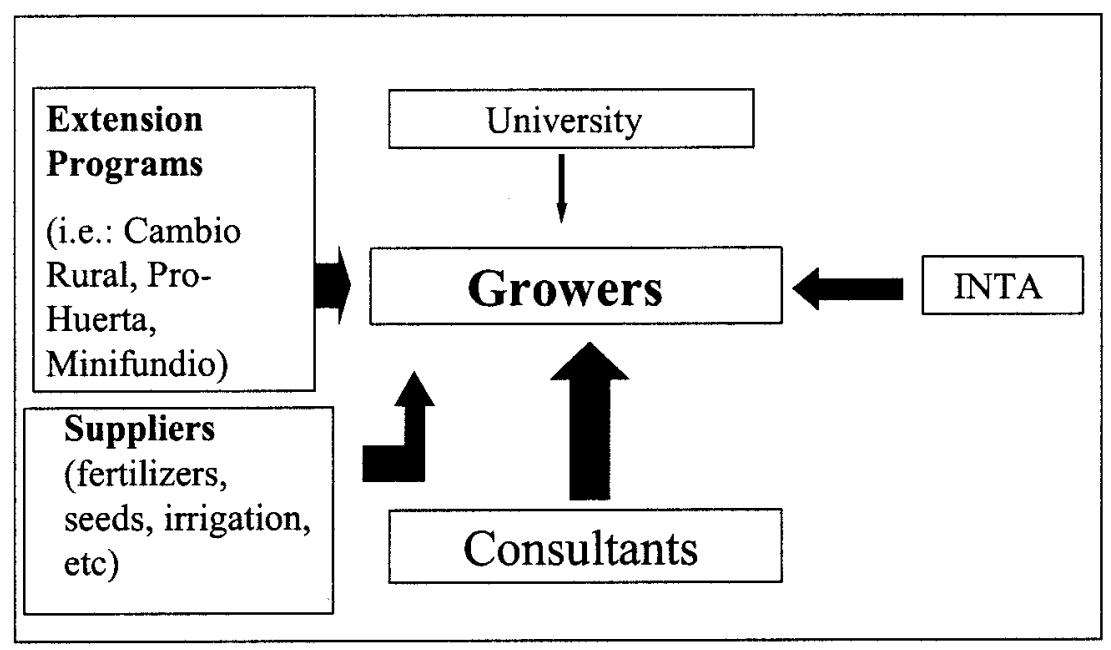

Fig. 3. Identification and magnitude of the main technological information sources for growers in Argentina (arrow size denotes relative importance of the channel). Cambio Rural = Rural Change National Institute of AgricultueTechnology; Prohuerta $=$ Food security program for poor people; Minifundio $=$ Program created to improve income and life quality of small growers; INTA = National Institute of Agriculture Technology.

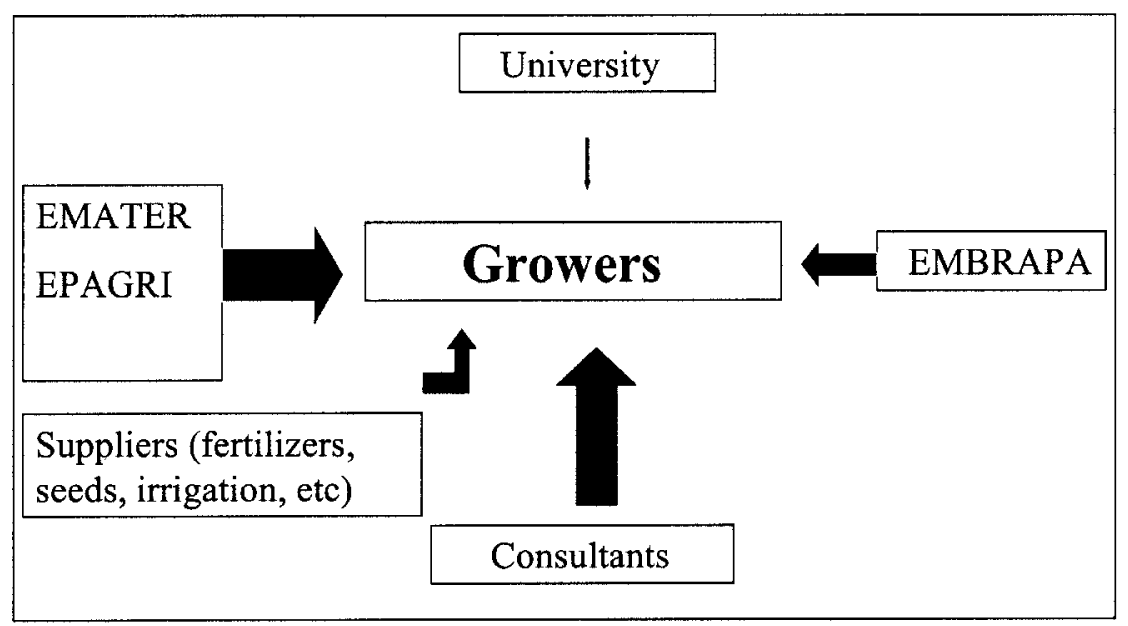

Fig. 4. Identification and magnitude of the main technological information sources for growers in Brazil (arrow size denotes relative importance of the channel). EMATER = Technical Assistance and Rural Extension Enterprise; EPAGRI $=$ Research and Extension Enterprise of the State of Santa Catarina; EMBRAPA = National Agriculture Research Enterprise of Brazil.

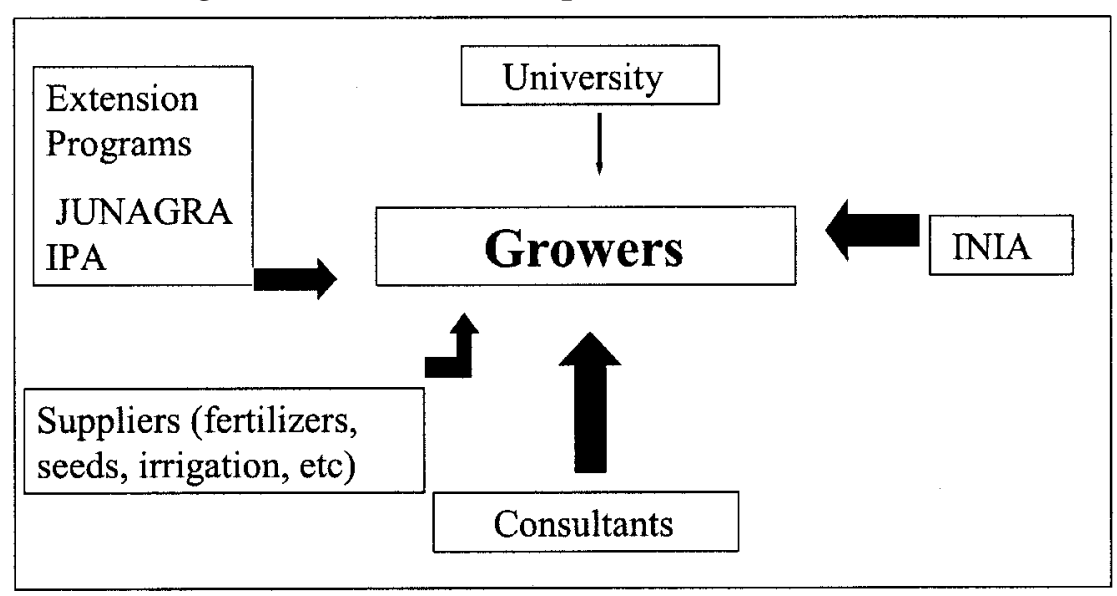

Fig. 5. Identification and magnitude of the main technological information sources for growers in Uruguay (arrow size denotes relative importance of the channel). JUNAGRA = National Fruit and Horticulture Council; INIA = National Agriculture Research Institute of Uruguay; IPA = Plan Farming Institute. information about production areas and productivity. Production problems, production areas, defining the best time for each country to export onions to other members of MERCOSUR are discussed. Production areas and research centers are visited during these meetings which provides better means for understand the differences and advantages of each country in regard to onion production.

Group technical assistance is increasing in the MERCOSUR countries especially in Uruguay and Argentina such as the CREA groups. The CREA experience with it participative methodology has been well received, not only in the development of productive and technological solutions, but also in aiding farmers and their families to become managers of their own enterprises. Technical assistance to individual farmers is provided mainly through individual advisors from nonprofit organizations (e.g., cooperatives) or through private participants.

As described, the information sources for growers arise from extension and research institutions, as well as from consultants and suppliers in Argentina, Brazil, and Uruguay (Fig. 3,4 , and 5 ). The relative size of each arrow represents its importance. It is clear that universities in MERCOSUR countries contribute much less to extension than do U.S. universities. The extension system in the U.S is organized through the university whereas in the MERCOSUR countries it is not.

Globalization and competitive markets demand innovation and highly efficient production from farmers. Therefore, it is necessary to increase the rate and effectiveness of technology transfer in order to optimize organizational effort, decrease overlapping effect and competition, and to support farmers in their efforts to respond to these difficult challenges.

\section{Literature cited}

Alemany, C. 2002. Los cambios de la extensión del Instituto Nacional de Tecnología Agropecuaria (INTA) y su relación con los paradigmas del desarrollo, p. 137-172. In: R. Thornton and G. Cimadevilla (eds.). La extensión rural en debate: concepciones, retrospectivas, cambiosy estratégias para el Mercosur. Ediciones Libros INTA. Buenos Aires, Argentina.

Allegri, M., B. Andre, and M.Villagran. 1987. Sistemas de transferencia de tecnología y extensión en el Uruguay, p. 97-106. In: J.M. Molestina (ed.). Dialogo XVII, Transferencia 
de tecnología agropecuaria en el Cono Sur. Convenio Instituto Interamericano de Cooperación para la Agricultura (IICA)/Banco Interamericano de Desarrollo (BID)/Programa Cooperativo para el Desarrollo Tecnológico Agroalimentarioy Agroindustrial del ConoSur (PROCISUR). Montevideo, Uruguay.

Allegri, M. 1999. Collaboration and accountability in agricultural research: The case of National Agriculture Research Institute (INIA), Uruguay. PhD thesis. Mich. State Univ., East Lansing.

Arboleya, J., G. Giménez, G. Galván, and H. González Idiarte. 1999. Tercera reunión científica de cebolla del MERCOSUR, Salto Uruguay. Memorias. Departamento de publicaciones de la Facultad de Agonomía, Montevideo, Uruguay.

Beintema, N. M., P. Zumbrano, M. Nuñez, and P.G. Pardey. 2000. Investigación \& Desarrollo (I\&D) agropecuario en Paraguay: Política, inversiones y perfil institucional. International Food Policy Res. Inst. (IFPRI), Dirección de Investigación Agrícola (DIA), y Fondo Regional de Tecnología Agropecuaria (FONTAGRO).

Burba, J.L. 1992. Curso taller sobre producción, comercialización e industrialización de ajo. 1-2. Instituto Nacional de Tecnología Agropecuaria (INTA) Estación Experimental Agropecuaria LA Consulta, Mendoza, Argentina.

Burba, J.L. 1993. Curso taller sobre producción, comercialización e industrialización de ajo. 3. Instituto Nacional de Tecnología Agropecuaria (INTA) Estación Experimental Agropecuaria LA Consulta, Mendoza, Argentina.

Burba, J.L. 1995. Curso taller sobre producción, comercialización e industrialización de ajo. 4. Instituto Nacional de Tecnología Agropecuaria (INTA) Estación Experimental Agropecuaria LA Consulta, Mendoza, Argentina.

Burba, J.L. 1997. Curso taller sobre producción, comercialización e industrialización de ajo. 5. Instituto Nacional de Tecnología Agropecuaria (INTA) Estación Experimental Agropecuaria LA Consulta, Mendoza, Argentina.

Burba, J.L. 1999. Curso taller sobre producción, comercialización e industrialización de ajo. 6. Instituto Nacional de Tecnología Agropecuaria (INTA) Estación Experimental Agropecuaria LA Consulta, Mendoza, Argentina.

Burba, J.L. 2001. Curso taller sobre producción, comercialización e industrialización de ajo. 7. Instituto Nacional de Tecnología Agropecuaria (INTA) Estación Experimental Agropecuaria LA Consulta, Mendoza, Argentina.

Caporal, F.R. 2001. La extensión rural en Rio Grande do Sul: de la tradicción "made in USA" hacia el paradigma agroecológico. Proceeedings of Foro Internacional para Empresas de Servicios Técnicos del Sector Agroalimentario, Mazatlán, Sinaloa, México. 22-24 Nov. 2001.

Empresa de Asistencia Tecnicay Extensao Rural (EMATER). 2002. Conheca a Empresa de Asistencia Tecnicay Extensao Rural. EMATER, 16 Oct. 2003. <http://www.emater.tche.br/ geral.php?menu=conheca.inc $/>$.

Empresa de Asistencia Tecnica y Extensao Rural de Santa Catarina (EPAGRI). 2002. A Empresa. EPAGRI. 16 Oct. 2003. <http: //www.epagri.rct-sc-br/empresa.html/>.

Ferrin, L.C. 1991. The small farmers' sector in Uruguay: A partnership in development cooperation. Inter-American Found., Arlington, Va.

Intituto Interamericano de Cooperación para la agricultura Agricultura (IICA). 2001. Agricultura en el MERCOSUR, Chile y Bolivia, p. 54-55. IICA Centro Regional Sur. Montevideo, Uruguay.

Instituto Nacional de Investigación Agropecuaria (INIA). 2000a. Estación Experimental INIA La Estanzuela: Breve Historia. INIA. 12 Oct. 2003. <http://www.inia.org.uy/ estaciones/la_estanzuela/estanzuela.htm/>.

Instituto Nacional de Investigación $\mathrm{Ag}$ ropecuaria (INIA). 2000b. Ley de Creación del INIA. INIA. 15 Oct. 2003 <http://www.inia.org.uy/lainstitución/ institución.htm/>.

Instituto Nacional de Investigación Agropecuaria (INIA). 2000c. Grupo de Riego y Agricultura Satelital (GRAS). INIA. 22 Oct. 2003. <http://www.inia.org.uy/disciplinas/ agroclima/index.html/>.

Instituto Nacional de Pesquisas Espaciales (INPE). 2002. Historia. Ministerio de Ciencia y Tecnología. INPE. 17 Oct 2003. <http:// www.impe.br/sobre_o_inpe/historia.htm/>. Instituto Nacional de Semillas (INASE). 2002. INASE en Breve. INASE. 15 Oct. 2003. <http: //www.inase.org.uy/Inaseenbreve.htm/>.

Instituto Nacional de Tecnología Agropecuaria (INTA). 2003a. Programa Cambio Rural. INTA. 22 Oct. 2003. <http: //www.inta.gov.ar/manfredi/actividad/ extension.htm/>.

Instituto Nacional de Tecnología Agropecuaria (INTA).2003b.ElPrograma Prohuerta. INTA. 16 Oct. 2003. <http://www.inta.gov.ar/ extension/prohuerta2.htm/>.

Instituto Nacional de Tecnología Agropecuaria (INTA). 2003c. El Programa Minifundio. INTA. 16 Oct. 2003 <http://www.inta.gov.ar/extension/ minifundio2.htm/>.

Instituto Nacional de Tecnología Agropecuaria (INTA).2003d. Sistemas Agrometeorológicos de apoyo a las decisiones agropecuarias. INTA Clima Agua Casterlar. 17 Oct. 2003. <http: //www.intacya.org.ar/>.
Instituto Plan Agropecuario (IPA). 2000. Editorial. IPA. 17 Oct. 2003. <http: //www.planagro.com.uy/publicaciones/ revista/R84/Edito84.htm/>.

Junta Nacional de la Granja (JUNAGRA). 2000. Información Institucional. JUNAGRA. 17 Oct. 2003. <http://www.mgap.gub.uy/ junagra/>

Marques, N.E. and F.T. Goes de Oliveira. 1987. Os sistemas de pesquisa e estensao rural no Brasil e o processo de transferencia de tecnología, p. 51-68. In: J.M. Molestina (ed.). Dialogo XVII, Transferencia de tecnología agropecuaria en el Cono Sur. Convenio Instituto Interamericano de Cooperación para la Agricultura(IICA)/Banco Interamericano de Desarrollo(BID)/Programa Cooperativo para el Desarrollo Tecnológico Agroalimentario y Agroindustrial del Cono Sur (PROCISUR). Montevideo, Uruguay.

Mercado Común del Sur (MERCOSUR). 2002. Aporte a la comprensión del MERCOSUR, Tratado de Asunción. Red Academica Uruguaya (RAU). 16 Oct. 2003. <http:// www.rau.edu.uy/mercosur/tratasp/>.

Ministerio de Ganadería Agricultura y Pesca (MGAP). 2000. Información Institucional: Cometidos sustantivos. MGAP. 13 Oct. 2003. <http://www.mgap.gub.uy/institucional/ institucional.htm/>.

Oliveira, M.M. 1999. As circunstancias da criacao da extensao rural no Brasil. Brasilia. Cadernos de Ciencia y Tecnol. 16:97-134.

Restaino, E. 1998. Prospección de la demanda: el caso de INIA Uruguay, p. 65-69. In: Puignau, J. (ed.). Dialogo XLVIII, Prospección de la Demanda y Evaluación del Impacto en la Investigación Agropecuaria.

Instituto Interamericano de Cooperación para la Agricultura (IICA)/Programa Cooperativo para el Desarrollo Tecnológico Agroalimentario y Agroindustrial del Cono Sur (PROCISUR). Montevideo, Uruguay.

Restaino, E. 2001. The research, technology transfer and extension system in Uruguay, p. 43-58. In: F.L. Brewer (ed.). Agriculture extension systems: An international perspective. Erudition Books, North Chelmsford, Mass.

Restaino, E. 2003. An examination of the Regional Advisory Councils of the National Agricultural Research Institute (INIA) of Uruguay: A case study of INIA La Estanzuela Research Station. MS thesis. Mich. State Univ., East Lansing.

Sawaya J.M., P. Garbarino, and A.N. Meloni, 1998. Estrategias Agroalimentarias del Mercosur, p. 20-31. In: Agricultura en el Mercosur, Chile y Bolivia. Instituto Interamericano de Cooperación para la Agricultura (IICA). Montevideo, Uruguay.

Secretariado Uruguayodela Lana(SUL). 2000. Organización y orientación estratégica. SUL. 20 Oct. 2003. <http://www.sul.org.uy/>. 